BIO-CONS, Jurnal Biologi \& Konservasi

Volume 3 No. 2, Desember 2021

p-ISSN : 2620-3510, e-ISSN: 2620-3529

\title{
EXPLORATION GERMPLASM OF TOBACCO IN EAST JAVA
}

\author{
Ismul Mauludin Al Habib*, Fatimatuz Zuhro \\ PGRI Argopuro University, Jember \\ Jl. Jawa Nomor 10 Sumbersari-Jember, Indonesia \\ *Email: ismul.habib1982@gmail.com
}

\begin{abstract}
Conservation of germplasm is absolutely necessary in order to repair a plant species. The first step in order to get the desired genetic properties is by germplasm exploration. The aim of this research was to get the germplasm of tobacco in East Java. Exploration was conducted in July, August and September 2018 in East Java. Determination of appropriate areas for exploration based on the result of discussion and suggestions from Department of Agriculture and leader in that community. The activity of exploration was conducted by researchers by come in the crop location directly. The result of this exploration showed that; (1). There are 16 types of tobacco in 6 districts of East Java province, among others; Krosok, Kasturi, Burley, Benyak, Semporis, Moris DB, Besuki, Tambeng, Kayu Mas, Mersi, BB, K3 19, Jowo, Krempol Jati, Prancak 95 and Jepon Raja, (2). There are similar types of tobacco in 2 districts (Probolinggo and Jember), namely Kasturi tobacco. This is related to the spread of demand for tobacco processing companies and exporters, as well as the geographical location of the region.
\end{abstract}

Keywords: Exploration, Tobacco 


\section{INTRODUCTION}

East Java is one of the tobacco-producing provinces in Indonesia. Tobacco growing area in East Java in 2015 reached 98.006 ha with production reaching 74.241 tons (Dirjenbun, 2015). Some of the areas in East Java that produce the best tobacco include; Madura, Jember, Situbondo, and Bojonegoro.

The optimal altitude for the growth of tobacco plants is 0 - 900 meters above sea level. Tobacco plants require temperatures ranging from $21-32.30^{\circ} \mathrm{C}$. Poor plant growth and low productivity can occur if the irradiation is less (Matnawi, 1997).

Haryanto (2013) reported that low-intensity rain that occurred throughout the night caused damage to tobacco plants and farmers failed to harvest. Crop failures due to light and long-lasting rains also occurred in 2014 to 2016. Damage to tobacco plants due to high rainfall was also reported by the Indonesian Tobacco Community Alliance (AMTI). In 2010, as many as 737 hectares of tobacco land in Lumajang were damaged.

One of the efforts to reduce farmers' losses due to crop failure caused by erratic weather changes is by assembling new varieties that are tolerant of high rainfall. These efforts must be initiated by knowing the desired traits, particularly related to their genetic characteristics.

The first step in knowing genetic traits is to find out the source of the expected gene. Gene sources can be obtained by way of exploration of the desired plant. Knowledge of genetic diversity is the basic capital for plant development and improvement. The more germplasm collected, the more profitable the plant breeding program will be. Breeding is a multidisciplinary applied science (Gepts and Hancock, 2006) involving agronomy, cytogenetics, genetics, physiology, botany, pathology, entomology, molecular, biochemistry, bioinformatics, and statistics.

Germplasm is the basic raw material for plant breeding. In the germplasm stored various diversity of characteristics possessed by each collection number (accession). Sastrapraja (1992) states that germplasm is a substance contained in a group of living things which is a source of hereditary traits that can be assembled to create superior types or new cultivars.

\section{METHOD}

Exploration in this study was carried out for 3 months, namely from January to March 2018 in East Java Province. Exploration was carried out in collaboration with the 
Department of Agriculture of Jember Regency. The determination of suitable areas for exploration is determined based on the results of discussions and suggestions from Department of Agriculture and local community leaders. Exploration activities were carried out by researchers assisted by technical personnel by visiting the location of the planting site. The germplasm is in the form of seeds, which are taken from the location, and then passport data is made (accession number/variety).

\section{RESULT AND DISCUSSION}

Exploration of tobacco plants was carried out in several districts which are centers of tobacco cultivation in East Java. The area includes; Jember Regency, Bondowoso Regency, Situbondo Regency, Probolinggo Regency, Bojonegoro Regency, Pamekasan Regency, Sampang Regency, Blitar Regency, Malang Regency, and Kediri Regency. The following is an accession of exploration results in East Java (Table 1.).

Table 1. Tobacco Cultivation Data in Jember Regency

\begin{tabular}{|c|c|c|}
\hline Nomer Aksesi & Nama Aksesi/Varietas & Kabupaten \\
\hline 1. & Tc 8212 & Blitar \\
\hline 2. & Gt & Blitar \\
\hline 3. & BP Jimanuk & Blitar \\
\hline 4. & Krempol kerep & Bojonegoro \\
\hline 5. & jowo Ros kerep & Bojonegoro \\
\hline 6. & K3 19 & Bojonegoro \\
\hline 7. & H362 & Bojonegoro \\
\hline 8. & Bojonegoro 1 & Bojonegoro \\
\hline 9. & Semporis & Bondowoso \\
\hline 10. & Kristian & Bondowoso \\
\hline 11. & Coker 176 & Bondowoso \\
\hline 12. & Sumoris & Bondowoso \\
\hline 13. & Mawar pink & Jember \\
\hline 14. & Benyak & Jember \\
\hline 15. & Kasturi & Jember \\
\hline 16. & Ts $54+$ tkd & Jember \\
\hline 17. & K 99 & Kediri \\
\hline 18. & Tc ml & Kediri \\
\hline 19. & H8 94 & Kediri \\
\hline
\end{tabular}


2021. BIO-CONS: Jurnal Biologi dan Konservasi. 3 (2):32-36

\begin{tabular}{lll}
\hline 20. & H a 320 & Malang \\
\hline 21. & Sgr k99 & Malang \\
\hline 22. & Nn 944 & Malang \\
\hline 23. & Tkd + h363 & Malang \\
\hline 24. & Hb 6-15 & Malang \\
\hline 25. & Opot & Pamekasan \\
\hline 26. & Prancak 95 & Pamekasan \\
\hline 27. & Kasturi kraksaan & Probolinggo \\
\hline 28. & Mersi & Probolinggo \\
\hline 29. & BB & Probolinggo \\
\hline 30. & Kasturi 933 & Sampang \\
\hline 31. & K 326 & Situbondo \\
\hline 32. & Bat 45 & Situbondo \\
\hline 33. & Tc 918 & Situbondo \\
\hline
\end{tabular}

Maesan district is the first area in Bondowoso Regency that developed a tobacco farming business. The first introductions were chopped tobacco of the types of Sompor and Moris. The planting of the two types of tobacco on land that was close to each other and lasts for years, is thought to naturally give rise to a new type which the local community calls Somporis. In 1989, Balittas conducted a survey on the performance of tobacco plants on the islands of Java and Madura. The survey results showed that the cultivars that developed in Bondowoso Regency were Somporis and Moris (Anonymous, 1989).

There are 2 areas in East Java that have the same type of tobacco grown by farmers. The similarity is closely related to the spread of demand for tobacco processing companies and exporters. The similarity is also related to the geographical location which is not much different in each region.

Efforts to manage and conserve biological natural resources cannot be separated from efforts to manage and conserve germplasm as carriers of the hereditary traits of these biodiversity species (Ja Posman Napitu, 2008). 


\section{CONCLUSION}

Based on the results of tobacco exploration in East Java, it can be concluded that:

1. There are 16 types of tobacco in 6 districts of East Java province, among others; Krosok, Kasturi, Burley, Benyak, Semporis, Moris DB, Besuki, Tambeng, Kayu Mas, Mersi, BB, K3 19, Jowo, Krempol Jati, Prancak 95 and Jepon Raja

2. There are similar types of tobacco in 2 districts (Probolinggo and Jember), namely Kasturi tobacco. This is related to the spread of demand for tobacco processing companies and exporters, as well as the geographical location of the region.

\section{REFERENCES}

Anonim. (1989). Survei Keragaan Tembakau Jawa Madura, Kerja Sama Balittas-PT Sampoerna Surabaya. Malang,Balittas.

Dirjenbun. (2015). Statistik Perkebunan Indonesia 2013-2015 Tembakau. Direktorat Jenderal Perkebunan. Kementrian Pertanian. Jakarta.

Gepts, P and Hancock, J. (2006). The Future of Plant Breeding. Crop Sci. 46:1630-1634.

Haryanto. (2013). Budidaya Tembakau: Catatan Kecil untuk Teman Agroteknologi : http://ilham-roby.blogspot.com/2013/12/budidaya-tembakau.html. Diakses pada t14 Desember 2017.

Ja Posman Napitu. (2008). Kajian Yuridis Plasma Nutfah Bagi Ketahanan Ekonomi Negara. Yogyakarta : Universitas Gadjah Mada.

Matnawi. (1997). Budi Daya Tembakau Bawah Naungan. Yogyakarta: Kanisius.

Sastrapraja, S.D. (1992). Sarasehan Plasma Nutfah dan Sistem Nasional Penanganannya. Yogjakarta. 7-9 Nopember 1990.Bogor: Komisi Pelestarian Plasma Nutfah Nasional. 